\title{
Yerli Dizilerde Kadın Kimliğinin Temsili Üzerine Bir Örnek; “Yaprak Dökümü" Dizisi
}

\author{
Pelin Erdal Aytekin (Dr. Öğr. Üyesi) \\ Adnan Menderes Üniversitesi İletişim Fakültesi \\ pelinerdala@gmail.com
}

Başvuru Tarihi: 26.12.2017

Yayına Kabul Tarihi: 24.04.2018

Yayınlanma Tarihi: 30.07.2018

Öz

Bu çalışma toplumsal cinsiyet bağlamında kadın kimliğinin medyada yer alış biçimini tartışmaya sunmaktadır. Toplumsal cinsiyet kavramı, günümüzün önemli araştırma alanlarından biridir. Özellikle kadın kimliğinin toplumsal kodlar içerisindeki konumu hem evrensel düzeyde hem de yerel unsurlar söz konusu olduğunda oldukça önem teşkil eder. Bu noktada medyanın konumsal belirleyiciliği, izler kitleyi yönlendirme becerisi çok uzun zamandır bilinmektedir. Özellikle televizyon mecrasını, bir sosyolojik olgu olarak, toplumsal cinsiyet çalışmaları ile bir araya getirmektedir. Tartışılan bu ifadeler doğrultusunda, çalışmanın ilk evresinde toplumsal cinsiyet kavramının ne olduğu üzerinde durulmuştur. Sonrasında ise kadın kimliğinin toplumsal düzlemde televizyon mecrası dahilinde ne gibi sorunsallarla birlikte okunabileceği açıklanmaya çalışılmıştır. Tüm bu bağlam takip eden bölümde, Türkiye'de kadının konumun belirlenmesi ve ortaya konulması gibi bir noktaya varmaktadır. Çalışmanın örneklemi, 2005-2010 yılları arasında beğeni ile izlenen ve kadın temsilinin ortaya konması açısından oldukça elverişli bir yapım olan "Yaprak Dökümü" dizisi olarak belirlenmiştir. Bu bağlamda, öncelikle bir tür olarak Türk yerli drama ürünü yapısal olarak ele alınmıştır. Farklı birçok 'kadın’ın temsil edildiği "Yaprak Dökümü" dizisi bu değerlendirmeyi genişletebilmek; kadın kimliğinin sınıfsal ve toplumsal farklılıklarını ortaya koyabilmek adına incelenmiștir.

Anahtar Kelimeler: Toplumsal Cinsiyet, Kadın ve Medya, Yerli Drama Yapısı. 
Research Article

\title{
An Example of Orientation A Women Identity In Indigenous TV Serials; "Yaprak Dökümü"
}

\author{
Pelin Erdal Aytekin (Asst. Prof.) \\ Adnan Menderes University Faculty of Communication \\ pelinerdala@gmail.com
}

Date Received: 26.12.2017

Date Accepted: 24.04.2018

Date Published: 30.07 .2018

\begin{abstract}
This study presents the way in which women's identity takes place in the media in the context of gender. The concept of gender is one of the important research areas of today. Especially the position of female identity in social codes is very important both at universal level and when local elements are concerned. At this point, the positional determinism of the media, the ability to direct the audience mass is known for a very long time. It brings together the television medium in particular, as a sociological phenomenon, with gender studies. In the light of these arguments, it is emphasized what the concept of gender is in the first phase of the study. Later on, it was attempted to explain how the identity of woman could be read along with the problems within the television medium on the social level. All this context, the following section is to reach a point of such determination and to determine the position of women in Turkey. The sample of the work was identified as the "Yaprak Dökümü" drama series, which was followed by appreciation between 2005 and 2010, and which was quite favorable for the presentation of the female representation. In this context, the Turkish native drama product was first structurally handled as a tv genre. The "Yaprak Dökümü" drama series, represented by many different 'women', can expand this assessment; in order to be able to reveal the class and social differences of female identity.
\end{abstract}

Keywords: Gender, Women and Media, Structure of Native Dramas. 


\section{Giriş}

Toplumsal yapı içinde kadın kimliğinin konumlandırılışı; sosyal, politik, ekonomik ve kültürel birçok dinamiğe bağlı olarak gerçekleşir. İlkel topluluklardan, modern toplumlara, kırsaldan kente, doğudan batıya kadının toplum içindeki bu yer alış biçimi ciddi farklılıklar göstermektedir. Ancak bu farklılaşma biyolojik olmaktan çok, toplumsal cinsiyet kavramıla yani cinsiyetin toplumsal temelde ayrışmasıyla ilgilidir. Bu ayrışma geçmişten günümüze zaman içerisinde farklılı göstermiş, anaerkil düzenden ataerkil düzene geçişle birlikte kadının toplum içinde konumu belirgin biçimde değişmiştir. Kadın kimliği bu ayrışmanın neticesinde ikincil bir konuma gerilemiş, hem ekonomik hem politik hem de sosyal özgürlügünü kaybetmiştir. Ancak Batı dünyasında gelişen insan hakları politikaları sonucunda kadın da, kimliğini ve özgürlüğünü tekrardan aramaya başlamıştır. Sonuç olarak dünden bugüne bu konuda önemli aşamalar kaydedilmiş, ilerleme her zaman beklendiği kadar hızlı yaşanmasa da en azından kadın kimliği üzerine konuşulmaya başlanmıştır. Ancak Türkiye konu ile ilgili çalışmalar yapmış olsa da devamında aynı hareketliliği gösterememiştir. Özellikle eğitim, çalışma, sosyal hayata katılma ve benzeri konulardan geri planda, ev içinde kalmış olan kadının bu çemberin içinde çıkmak konusunda ciddi çabalar göstermesi gerekmiştir. Yine de kaydedilen aşamanın tatmin edici bir noktaya gelememiş olduğu söylenebilir. Türk kadınının halen bu konuda dikkatle kaydetmesi gereken önemli mesafeler vardır.

Geniş kitlelere hitap ettiği ve etkilediği düşünülürse, medya ve kadın ilişkisi de konu dâhilinde oldukça önemli bir yere sahiptir. Kadının medyada yer alış biçimi genellikle sistemin, ataerkil düzenin devamını sağlamaya hizmet etmektedir. Diğer taraftan genel bir ifadeyle, kadın izleyicinin ekranda gördükleri karşısında özdeşleşme yaşaması ve bu yolla sosyal doyuma ulaşması konuyu daha da hassas bir noktaya çekmektedir. $\mathrm{Bu}$ noktada özellikle yerli drama yapımları gibi hem prime-time kuşağında yer alan hem de ekranları uzun sürelerle işgal eden program türlerinin dikkatle incelenmesi faydalı olabilir. Ancak bu analizin yapılması amacıyla öncelikle toplum ve kadın kimliğinin ilişkisi incelenecektir. Toplumsal cinsiyet kavramı ve farklılaşması üzerinde durulacak, kadın haklarının Türkiye ve dünya bağlamında gösterdiği gelişmeye değinilecektir. İkinci bölümde yine konunun ana başlığını oluşturan medya ve kadın ilişkisi irdelenecektir. Son bölümde ise kadın kimliğinin Türk dizilerinde yer alış biçimine örnek oluşturabilecek Yaprak Dökümü dizisinin analizi yapılmaya çalışılacaktır. Böylece kadın kimliğinin, öncelikle toplumsal alanda sonrasında medyada ve belirgin bir örnekle bir yerli yapım dramada yer alış biçimi ele alınacaktır.

Çalışmada, sorunun analizi konusunda betimleyici analiz yöntemini kullanılmıștır. Araştırmanın literatür çalışması yapıldıktan sonra örneklem olarak seçilen "Yaprak Dökümü" dizisi, beş ana kadın karakterin, kadın kimliğinin cinsiyettemsili bağlamında incelenmesi ve bu incelemenin sonunda kadın kimliğinin "Yaprak Dökümü" özelinde cinsiyet rollerinin yeniden üretilmesi konusundaki katkısı açıklanmaya çalışılacaktır.

\section{Toplumsal Cinsiyet Kavramı ve Cinsel Farklılaşma}

Kottak (2001, 443); toplumsal cinsiyet rollerini, bir kültürün cinsiyete atfettiği görevler ve etkinlikler ya da erkek ve kadın karakterlerine ilişkin basitleştirilmiş fakat güçlü bir şekilde benimsenmiş düşünceler olarak tanımlar. Butler (2008, s. 50 ) ise toplumsal cinsiyeti "cinsiyetli bedenin üstlendiği anlamlar bütünü" olarak 
açılar. Connell da (1998, s. 114) benzer bir ifadeyle bedenin "toplumsal cinsiyeti barındıran süreçlerin bir parçası" olduğundan bahsederken ama der "öyleyse beden her türlü toplumsal pratiğin de bir parçasıdır."

Görülmektedir ki yapılan bu tanımlamalar, sosyal-toplumsal algılamamızın içinde cinsler arası bir farklılaşmaya işaret etmektedir. İki farklı cinsiyet arasında biyolojikfizyolojik temelli farklılıkların mevcudiyeti bunları toplum için ayrıştırma ihtiyacını doğurmaz. Farklı fiziksel özelliklere ya da güce sahip olmak statü anlamında bir cinsi diğerinden üstün kılmaz ya da aşağı göstermez. Bu olsa olsa kültürlerin ve insan topluluklarının yarattığı bir sınıflandırmadır ve hemen birçok kültürde ve toplumda belirli zaman ve hallerde belirli ayrışmalara sebebiyet verebilir. "Fakat toplumsal cinsiyet, bir kültürün kadına ve erkeğe atfettiği ve telkin ettiği tüm özellikleri kapsar" (Kottak, 2001, 443). Butler (2008, s. 54) feminist teorinin toplumsal cinsiyeti; cinsiyetin kültürel bir yorumu, kültürel bir inşası olarak gördügünü söylerken esasen "inşa" sürecinin altını çizmektedir. Bu nedenlerle kadının toplumsal yapı içindeki yeri ve konumunun; fizyolojik özelliklerin farklılaştırdığı cinsiyete bağlı olarak değil de kültürel kodlara ve dinamiklere bağlı olarak şekillenen toplumsal cinsiyete dayalı olduğunu söylemek yanıltıcı olmaz. Bu tespitin en önemli dayanağına, modern dünyanın dışına çıkıldığında, bazı ilkel toplulukların kadın ve erkeği konumlandırışında rastlanır.

1930'lu yıllara kadar süren çalışmalarda biyolojik determinizm bakış açısıyla kadın ile erkek arasındaki ayrımın, genetik-cinsel ya da biyolojik-fizyolojik olduğu kabul ediliyordu. Ancak antropolog Margaret Mead'in 1935 yllında yaptığı bir saha araştırmasıyla bu bakış açısı değişti. Arapesh, Mundugumor ve Çambuli kabileleriyle yapılan araştırmalarda, kadın-erkek rollerinin, Batı'da algılanandan farklı olduğu görüldü. Yapılan bu saha araştırmasında; Arapesh'li kadın ve erkekler, Batı kültüründeki kadın rolünü benimserken, Mundugumor'lu kadın ve erkeklerin ise Batı'daki erkekler gibi davrandıklarına rastlandı. Daha da dikkat çekici olanı, Çambuli kültüründeki kadınların Batı kültüründeki erkekler gibi, erkeklerin ise kadınlar gibi davranıyor olmalarıydı. Bu araştırmanın sonuçları, kadın-erkek rollerinin ve ayrımının çoğunlukla kültürel öğretilerden kaynaklanan öğrenilmiş bilgilere dayandığını gösterdi (Güvenç, 1999, 226). Burada görülmüştür ki, kültürel kodlamalara göre belirlenen cinsiyet rolleri ister büyük olsun ister küçük, bir toplumdan diğerine farklılıklar gösterebilmektedir. Modern toplumlarda bu yönde belirli standartlar olsa da özellikle daha izole ve daha küçük gruplar toplumsal cinsiyetle ilgili farklı refleksler geliştirebilmişlerdir. Örneğin Şirin Tekeli, sınıfsız olan bu toplumlardaki kadın ve erkeklerin eşit statüde yer almadıklarını, kadınların "politik iktidar"ın dışında kaldığını öne sürer. Yine de der, bu statü farklılaşması kadınları toplumsal yaşantıdan izole etmez ve kadınlar bu topluluklarda erkekler kadar katılımcılardır. Üstelik bu toplumlarda aile ve toplum ikileşmesi yoktur ve bu nedenle de kadın eve kapatılmış değildir. "Bu toplumlarda statü farklılaşmaları genellikle; yaş, cinsiyet ve fiziki güç farkları gibi, doğa karşısında güçsüz olan insanın doğasında olan farklardan kaynaklanmaktadır (Tekeli, 1982, 55)". Elbette ki bu örnekler, bu uygulamaların bütün ilkel topluluklar için geçerli olduğunu göstermez. Ancak bunun gibi verilebilecek birkaç örnek bile kadın-erkek (cinsiyet) farklılaşmasında kültürel boyutun göz ardı edilemeyecek kadar önemli olduğunu ortaya koymaktadır. 
Peki, bu toplumsal farklılaşma kimin icadıdır ve bir başlangıcı varsa; ne zaman, hangi sebeplerle ortaya çıkmıştır? Bu cevabı verebilmek için anaerkil topluluklara kadar gitmek gereklidir. Denilebilir ki anaerkillikten ataerkilliğe geçiş, hemen hemen özel mülkiyetin ortaya çıkışıyla eş zamanlıdır. Kadınla erkeğin eşit toplumsal koşullara sahip olduğu, üretim araçlarının ortak mal olarak kullanıldığı, avcı toplayıcı anaerkil klanlar, tarımın başlaması ile geçilen yerleşik düzende özel mülkiyet kavramı ile tanışmış ve böylece yaşanan birçok toplumsal değişimin yanı sıra cinsiyetler arasında da belirgin bir farklılașma meydana gelmiştir. "Metallerin bulunuşu, hayvanların yetiștirilmesi, dokumacılığın ve tarla kültürünün gelişimi sonucu ortaya çıkan artı değerin aile mülkiyetine geçişiyle erkeğin ve kadının rolleri değişerek statüleri arasındaki eşitlik bozulmuştur (Tan, 1979, 164)”.

Öne sürülen görüş; kadın ve erkek arasındaki toplumsal farklılaşmanın, kadının ekonomik yönden eşit ölçüde geçime katkıda bulunması halinde azaldığı, tersi durumda ise ciddi bir artış gösterdiği yönündedir. Örneğin avcl-toplayıcı gruplarda erkeğin beslenmeye katkısının kadından çok olduğu durumlarda toplumsal cinsiyette farklılaşma daha belirginleşmektedir. Ancak toplayıcılığın öne çıktığı durumlarda mevcuttur ki burada da toplumsal cinsiyet statüsünde, beslenmenin avcılık ile sağlandığı koşullardan daha fazla eşitlenme yaşanır (Kottak, 2001, 444).

Tarıma geçiş hiç kuşkusuz toplumsal yapılanmayı önemli ölçüde değiştirmiştir. Aynı değişim toplumsal cinsiyetin farklılaşmasında da görülür. Avcı-toplayıcılıktan, tarımsal üretime geçildiğinde üretici olarak kadının statüsü ikinci sıraya düşmüştür. Özellikle saban sürme gibi fiziki güce ihtiyaç duyulan bazı tarım tekniklerinin uygulanmaya başlaması bu anlamda erkeği ön plana çıkarırken, kadını da ikinci plana düşürmüştür. Bu gelişme ile birlikte kadın önemli ölçüde üretimden kopmuş, aynı zamanda aile yapılanmasındaki değişim de bu kopuşu desteklemiştir. Çekirdek aile daha yaygın hale gelmiş, kadının cinselliği de böylece daha sıkı bir denetim altına alınabilmiştir (Kottak, 2001, 453). Ancak burada önemli olan mülkiyet kavramının ortaya çıkışıdır.

\footnotetext{
“Toprağa bağlanma, tarla kültürünün gelişmesi, hayvanların çoğalması, verimin artması, artan ürünün aile mülkiyetine (özel mülkiyete) geçmesini sağlamış, bu durum cinsler arasındaki dengeyi kadının aleyhine bozmuştur. Çünkü özel mülkiyet, sınıf ayrımını ve ayrımı yaratan kurumları beraberinde getirmiștir. Bu düzen içerisinde erkek üretim araçlarına, mülke, silaha ve tutsaklara sahip olmuştur. Mal varlığının çocuklara geçirilmesinin gerekliliği, erkeğin babalığının pekişmesine, kadınınsa yalnızca ait olduğu erkeğe sadakatle bağlı tutulmasına yol açmıştır. Her şeyi elinde bulunduran baba, kadının da sahibidir (Elmacl, 1996, 81-82)".
}

Toplumsal cinsiyet kavramındaki değişim yukarıdaki yazıda özetlenen şekilde gelişmiştir. Özellikle ekonomik ve politik bazı gelişmeler kadının toplum içindeki konumunda değişiklikler meydana getirmiş ve bu doğrultuda gündeme gelen her yeni sistem, kendi dengelerini kurabilmek adına kadının toplumsal konumunu şekillendirmeye çalışmıştır. Bu gelişmeler bazen olumlu bazen olumsuz ise olsa bile bu durumla mücadele etmeye çalışan kadın hareketleri, kadın haklarında belirli mesafelerin kaydedilmesini olanaklı hale getirmişlerdir.

\section{Toplumsal Cinsiyet Bağlamında Türkiye'de Kadının Toplumsal Konumu}

Toplumsal cinsiyet kavramının kültürel yönde farklılaşması gibi, cinsiyetler arasındaki farklılaşma da toplumdan topluma değişiklikler gösterebilmektedir. Türkiye kadın ve erkek arasındaki farklılașmanın yüksek olduğu ülkelerden biridir. 
Bu farklılaşma özellikle kır ve kent arasında da değişiklikler gösterir. Kırsal alandaki kadının konumu, toprakla iç içe geçmiş durumdadır. Ataerkil aile tipi, toprağın erkekler aracılığıyla kuşaktan kuşağa aktarımını sağlarken, erkeği öne çıkaran bu tutum kadına da oldukça dar bir alan bırakır. Bu nedenle kadın toplumsal alan içinde, ekonomik katkısıyla doğru orantılı bir konuma sahip olamamaktadır.

Kandiyoti (1997), basit bir değerlendirilme yapıldığında dahi kadınların kırsal alandaki konumunu belirleyen öğelerin aşağı yukarı aynı olduğunu söylemektedir; çocuk doğurma (doğan çocuğun cinsiyetine göre farklılık gösterebilmektedir) ve yaşlanma. Önce çocuk doğurduğunda - özellikle de erkek çocuk doğurduğunda - daha sonra da yaşlandığında statü kazanan kadının toplumsal alan içindeki konumu, üretimdeki yeri ne olursa olsun genellikle çok görünür değildir. Kamusal alanla ilgili işler ve uzmanlık gerektiren uğraşlar erkek tekelinde bulunmakta, bu durum da kadının emeğini denetleyememesi sonucunu doğurmaktadır. $\mathrm{Bu}$ akış, kadının kendi işgücü konusunda söz sahibi olamamasıyla ve özgürleşememesiyle devam eder (s. 45). Diğer taraftan eğitim alanındaki geri kalmışlıkta, Türkiye'deki kadının özellikle kırsal alandaki konumunu etkilemektedir. Örneğin kentsel alanda kadınların \% 18.7'si okuma yazma bilmezken, kırsal alanda bu oran \% 30.4'e çıkmaktadır. Özellikle Doğu ve Güney Doğu Anadolu Bölgesi'nde ortalama bir değerlendirmeyle her 10 kadından 5'inin okuma yazma bilmediği, dünyaya gelen kız çocuklarının da yaklaşık olarak \%17'sinin hayatı boyunca okuma-yazma öğrenecek şansa hiç sahip olmadığı görülmektedir. Gelir dağılımından elde edilen pay ve eğitim olanaklarından yararlanma hususunda da kadın ve erkek arasında ciddi bir adaletsizlik bulunmaktadır. Yine özellikle Doğu ve Güney Doğu Anadolu Bölgesi'nde kadınla erkek arasındaki bu fark ikiye katlanmıştır (Hablemitoğlu, 2004, 19-22). Ataerkil yapı, diğer bir deyişle mülkiyet ve işgücünün değerlendirilememesinin yanı sıra eğitim ve okuma-yazma konusundaki geri kalmışlık, kırsal alandaki kadının konumunun iyileşmesine engel teşkil etmektedir.

Kandiyoti (1997), kentteki kadının, kırsal kesimdeki kadından daha farklı bir konuma sahip olduğunu söylemektedir. Buradaki farklılık daha çok, kentteki kadının tanımlanması ve sınıflandırılması zor çeşitliliğinden kaynaklanmaktadır. Bir tarafta kırsal alandan kente gelmiș ve geldiği yerde farklı bir toplumsal yapılanma meydana getirmiş gecekondulu kadın, diğer tarafta ise daha eğitimli, bu nedenle hayattan beklentileri daha yüksek, 'Batılı' bir bakışa sahip üst orta sınıf kadını, kentteki kadın imajında önemli bir çeşitlilik meydana getirmektedir. Yine de özellikle eğitimli üst orta sınıf kadını, kırsal kesim ya da gecekondu kadınından belirli ölçüde farklılaşmıştır. Özellikle meslek sahibi kadınlar, iş ve ev sorumlulukları, çocuğun büyütülmesi gibi konularda diğer 'yardımcı kadın'a ihtiyaç duymaktadırlar. Bu nedenle meslek sahibi, eğitimli, üst-orta sınıf kadın ev ile ilgili sorumluluklarından biraz da olsa uzaklaşmakta ancakyine de bu alanı erkekle eşitoranda paylaşmamaktadır. Bu durumda çözümü yine kadın getirirken, bu yeni yapılanmadan en az etkilenenin erkek olduğu söylenebilir (ss. 46-47). Bu gibi nedenler kentteki kadının rolünün bir miktar değişmiş olduğunu gösterse de, gerçek bir değişim ve farklılaşmadan söz edilemez. Hatta kadının ikiye katlanmıș olan sorumluluğu özellikle alt orta sınıf kentli kadının hayatını daha da ağırlaştırmıştır. Böylece ekonomik zorluklar nedeniyle çalışmak zorunda kalmış ancak yine ekonomik zorlukların varlığı nedeniyle, üst orta sınıf kadın gibi "yardımcı kadın" desteğine başvuramamış bu nedenle de ev içi sorumlulukları da kendi yerine getirmek durumunda kalmıştır. Bu durum da kadının yükünü ikiye katlamıştır. 
Genel olarak, ataerkil toplumların tümü için geçerli olan geleneksel ideolojinin cinsiyetçi işbölümü, kadının toplumsal konumunu öncelikli olarak ev kadını ve anne olarak belirlemiștir. Bu yapılanma kadının ikinci dereceden emek kaynağı olmasına sebebiyet verir. "İşleri toplumsal cinsiyet açısından kategorilere ayıran bu anlayış, kadını toplumsal üretime 'ev kadınlığı' statüsünü koruyarak ve ancak kadın emeğini gerektiren zorunlu durumlarda dahil eder (Arat, 1996, 45)”. Böylece kadının belirlenmiş olan konumunun dıșına çıkması zorlaşır. Bu konum kadının içinde yer aldığı varsayılan sınıfa göre azalma ve çoğalma ya da farklılık gösterebilir. Yine de, alt orta sınıf kadınından beklenen 'ev kadınlığı' rolü daha belirginmiş gibi görünse de üst orta sınıf kadın da belirli sorumlulukları yerine getirmek durumundadır.

Bu sorumluluklar kimi zaman dile getirilmese de toplumsal alt metinlerde bu rollerin kime ait olduğu belirtilmiștir.

Diğer bir soruna ise kadınların çalışma koşulları sebep olmaktadır. Türkiye’de kadın işgücünün büyük bir oranının hâlihazırda ücretsiz aile işgücü statüsünde yer alması ve bu nedenle sosyal güvencesiz, uygun olmayan çalışma koşulları, kadının önünde önemli bir sorun olarak durmaya devam etmektedir (Hablemitoğlu, 2004, 18). Necla Arat'ın (1996) ifadesiyle;

\footnotetext{
"toplumsal ve ekonomik statü düşüklüğü nedeniyle hukuksal ve ekonomik açıdan erkeğe bağımlı bulunan geleneksel, dinsel, töresel baskılarla sindirilip edilginleştirilen ve eğitim eksikliği yüzünden büsbütün güçsüz kalan kadınlara yeniden üretim işlevi ve sosyalizasyon sürecinin tüm sorumluluğu da yüklenmiş olduğu için, iş bulup çalışma yaşamına katılma olanakları çok zayıftır (s. 53)".
}

Bu durumda yine kadının tek başına, bu sorunların ve sistemin üstesinden gelmesini beklemek ve bu konuda kadını yalnız bırakmak, kadının üzerine ekstra yük yüklemekten başka bir anlam ifade etmez.

\section{Medya ve Kadın}

Medyanın değiştiriciliği ve dönüştürücülüğü üzerine üretilen bütün söz ve söylemler sonuç olarak kitle iletişim araçlarının önemi konusunda uzlaşmaya varmaktadırlar.

"Kitle iletişimi, başat kültürü diğer alt kültürlerde belirli derecede geçerlik kılmak ya da başat kültür öğelerini bu alanlarda da etkinliğe kavuşturmak amaciyla topluma - toplumdaki egemenlik yapısını yansıtan ve haklılaştıran - bir hegemonik ideoloji sunmak ve benimsetmek işlevi denebilecek bir kültürel işleve (Oskay, 2000, 26)" sahiptir.

Bu yönüyle medya; politik ve ekonomik gündemin veya genel bir tanımlamayla sistemin etkisi altında kalmakta ve içeriğini yönlendiren bu unsurların devamına hizmet etmektedir denilebilir. Geniş kitlelere hitap ediyor olması da medyanın, sistemin ve geçerli değerlerin dışına çıkmasını zorlaştırır. Hali hazırda toplumsal birçok çıkmaza sebep gösterilen medya bu nedenlerle alternatif bir anlatıma başvuramaz. Kısacası medya; kapitalist, ataerkil ve egemen yapının devamını sağlayan önemli ayaklardan biri olarak kabul edilir ve kendine düșen görevleri yerine getirmesi salık verilir.

"Medya, kadınlar ve dişilik hakkında sırasıyla stereotipik, ataerkil ve egemen değerleri aktaran temel araçlar olarak algılanır (Zoonen, 1996, 487)”. Bu değerlere bağlı kalınmak suretiyle kadın medyada ya korunması gereken, masum, saf, anne ya da eş olarak ya da basit, fettan, cinselliği ön plana çıkarılmış kötü kadın olarak yer almaktadır. Her konumda genellikle ikinci plandadırlar ancak gençlerse mutlaka 
güzeldirler. Çalışıyorlarsa ev işlerini ikinci plana düşürmeyecek geleneksel kadın mesleklerinde çalışıyorlardır. Öncelik hep anneliğe verilmektedir. Böylece kadının birincil görevi annelik olarak belirlenmektedir. Özellikle reklam filmlerinde kadının; iyi çamaşır yıkaması, iyi yemek yapması, süper anne ve anlayışlı eş olması gerekir. İdeal kadının imgesinin altı bu yolla çizilmiş olur. "Bilişsel psikoloji geleneği içinde yapılan deneysel araştırmalar, medyanın -aile ile birlikte- toplumsallaştırma aktörü olarak hareket ettiği varsayımını desteklemektedir. Medya ve aile çocuklara, özellikle kendilerine uygun cinsiyet rolleri öğretmektedir... (Zoonen, 1996, 473-474)". Böylece toplumda genellikle genel-geçer kurallara göre belirlenmiş olan roller; kadınlara, çocuklara ve erkeklere aktarılır. Neyin, nasıl yapılması gerektiği, kimin görevinin ne olduğu, kimin ne yapması ya da yapmaması gerektiği bu yolla anlatılmış olur.

Zoonen (1996) "Medyada Feminist Yaklaşımlar" makalesinde konuya daha farklı bir yönden yaklaşmaktadır. Ona göre kadınlar, medya metinlerinde ifade edilen egemen kültürün kurbanı olarak algılanır ve onların güçsüzleştirici imgeler tarafından bombardımana tutuldukları düşünülür. Ancak diye devam eder Zoonen (1996), "insanlar medyayı sadece egemen kültürün ifadeleri olduğu için seçmezler, medyayı ayrıca kadınlar ve erkekler olarak kendileri hakkında bir şeyler ifade etmek için de kullanırlar... Kadınlar, farklı kadın özne konumlarını bulmak ve denemek için medyayı düşlem düzeyinde kullanabilirler (s. 501)". Özdeşleşmeye ihtiyaç duyulduğunda ya da roller karmaşıklaştı̆̆ında, medya kanaat önderleri ya da kabul gören rol modelleri olarak kullanılabilir. Sonuç olarak kadın ekranda; kendi hayatında yaşadığını, yaşaması gerekeni, yaşamak istediğini ya da yaşayamadığını gördüğünde onunla özdeşleşme yoluyla sanalda olsa bir rahatlama duyabilir.

Medyanın kadının hangi kesimine seslendiği de önemlidir. Eğitimli kadına hem çalışması hem de çocuk sahibi olup, evini temiz tutup, güzel yemekler yaparak ailesini mutlu etmesi gerektiği söylenirken; alt sınıftan, eğitimsiz kadına sınıf atlaması gerektiği mesajı verilir. Burada önemli olan dâhil olmayan grubu da tüketim ağına katmaktır. Bu bazen magazin programlarında yansıtılan dünyanın idealize edilmesi ile bazense yerli drama dizilerinde mekânın ve hikâyenin kullanımı ile yapılır. Bunu gerçekleştirmek için oldukça yalın bir dil kullanan medya, bu kullanımıyla hemen her kesimden kadına etkili biçimde nüfus edebilmekte ve onlara aslında yaşamaları gereken hayatları göstermektedir.

İzleyici olan kadına bakıldığında onun izleyici olarak gerçek yaşamında var olan role uygun şekilde konumlandığı görülür. Bu demektir ki geleneksel ataerkil yapı içine yaşamakta olan bir ev kadını "kurgusal iletileri" gerçek hayatı yansıttığı farz edilen haber programlarına yeğlemektedir. Bu nedenle televizyonun içeriği kadın ve erkek dünyasını birbirinden ayırı. Yerli dramalar, pembe diziler, magazin programları ve benzeri programlar, kadın dünyasını yansıttığı ileri sürülerek ev kadınlarına sunulurken haber ve haber programları erkek dünyasına ait oldukları düşünülerek dışlanır. Böylece erkek dünyasına ait olan çalışma yaşamı ve siyaset gibi konulara kıyasla kadınsı değerler ikinci plana atılarak önemsizleştirilmiş olur.

Sonuç olarak medya ve özellikle televizyon dünyası, kadın ve erkeğin ilgi alanlarını birbirinden ayırarak cinsel farklılaşmayı desteklemiş olur (Türkoğlu, 2000, 80-81). Ancak toplumsal cinsiyet farklılaşmasına tek sebep olarak medya gösterilemez. Sonuç olarak toplumsal cinsiyeti oluşturan kalıplar, toplumsal karşılıkları olan gerçekliklerdir (Zoonen, 1996, 489). Dolayısıyla medya, toplumsal gerçeklikleri 
çarpıttığı ya da cinsiyet ayrışmasını körüklediği yönünde tek başına suçlanmamalıdır.

Yapılan bir araştırma, çocukların zaman içerisinde toplumsal cinsiyet farklılıklarını onaylar hale geldiğini ortaya koymuştur. Araştırmanın sonuçlarına göre yaşları daha küçük olan çocuklar kendi cinsiyetlerini karşı cinse göre daha üstün bulmaktadır. Ancak yaşlar büyüdükçe kız çocuklarının kendi cinsiyet rollerine, erkeklere göre daha kuşkulu yaklaşmakta olduğu saptanmıștır. Bu kuşkunun kaynağının ise kadınların kendilerini erkekler için var olan cinsel varlıklar olarak tanımlamaya başladıkları cinsel toplumsallaşma sürecinin yol açtığı söylenebilir (Nare, 1996, 201-202). Burada da görülmektedir ki toplumsal bazı dinamiklerin varlığı medyadan ve medyanın gücünden çok öteye uzanmaktadır. Medya burada ancak sistemin devamını sağlayan bir görev üstlenmesi nedeniyle eleştirilebilir.

Zoonen (1996) toplumsal cinsiyetin farklılaşması konusunda medyaya ayrılan rolün; medyanın ekonomik yapılar içindeki konumuna, özelliklerine, yayınladığı program türlerine ve izleyicilerin gündelik yaşamlarında işgal ettikleri yere bağlı olarak değiştiğini ileri sürmektedir (s. 495). Ancak bu pay günümüzde, medyanın hem ekonomik konum içindeki oranı itibariyle hem de izleyici kitlenin gündelik yaşamında kapladığı yer itibariyle ciddi bir oranda artış göstermiştir. Bu ayrışmaya çözüm öneriliyorsa da öncelikle toplumsal cinsiyetin ayrışma biçiminin evrensel değil, toplumsal bir sürecin ürünü olduğu göz ardı edilmemelidir. Dolayısıyla eğer bir sorundan bahsediliyorsa bunun çözümü tarihsel bağlamda erkek ve kadın arasındaki bu ayrışmanın nasıl ve neden ortaya çıktığının, egemen gücün niteliklerinin ve hâkimiyet kurmanın sebepleri üzerinde durulmalı, öncelikle bunların çözümlemesi yapılmalıdır (Zoonen, 1996, 487). Sorunun kökenine inilmesi elbette ki değişimin niteliğini de etkileyecektir.

\subsection{Yerli Drama Yapısı ve Toplumsal Cinsiyetçilik Bağlamında Kadın Kimliğinin Temsili: "Yaprak Dökümü" Dizisi}

\subsubsection{Yerli Drama Yapısı}

Televizyonun yaygınlașması, kitle iletișim anlayıșını bir boyuttan başka bir boyuta taşımış ve içeriği görsel imajla bütünlemiştir. Görselliğin ön plana çıkması, içeriğin belirlenmesinde de yeni bir gündem meydana getirmiștir. Ekranın bu cazibesi zaman içinde daha çok kişiyi kendine çekmiş ve gündelik yaşamı ekrana, ekrandaki yaşamı ise gündelik hayata getirip götürmüştür. Bu yolla belki de hiçbir kitle iletişim aracının etkilemediği kadar kültürel-toplumsal alanı etkisi altına almıştır. Bunun en can alıcı yansımalarından biri de televizyon dramalarıdır.

Genel bir yargı özellikle yerli dramalarda temsil edilen kültürün Türk kültürünü yansıtmadığı yönündedir. Özellikle son dönem yerli dizilerde konu edilen malzeme ve görünüm, ülkenin genelini yansıtmıyor olsa da hedeflenmesi istenen hayat tarzını yansıtmaktadır. Gündelik hayat içinde bulunulamayacak mekânlar ve atmosfer bu dizilerde yakalanarak, düşlenen hayat tarzına ulaşılmaktadır. "Ekranın sunduğu imgesel karakterler ve durumlar ile dolu bu dünyanın, zaman içerisinde, izleyicinin gerçek dünyadan beklentilerini biçimlendirdiği ileri sürülmektedir (Çaplı, 2002, 126)". Böylece bireylere, nasıl bir hayat istemeleri gerektiği bilgisi verilerek bu yönde mücadele etmeleri gerektiği mesajı iletilmektedir.

Cankaya (2003) dramanın sinemadan televizyona geçişinin 1940'lı ve 50’li yıllarda yaşanmış olduğunu söylemektedir. 1950'li yıllarla birlikte televizyonun 
yaygınlaşmaya başlaması sinema izleyicisini ekran karşısına geçirmiş ve bu tarihten itibaren izleyicinin zaten alışık olduğu drama bir tür olarak televizyondaki yerini almıştır. Televizyon dizisi olan ilk dış kaynaklı yapımlar Türkiye'de ise ilk kez 1972 yılında yayınlanmaya başlamıştır (s. 73). 0 günden bugüne televizyon draması ister yabancı kaynaklı olsun ister yerli hemen hiçbir zaman popülaritesini kaybetmemiştir.

Ancak 1990 sonrasının çok kanallı televizyon ortamı farklı temaların yer aldığı, çeşitli toplumsal ilişkilerin görünür hale gelmesini olanaklı kılan bir alternatif sağladığı için bu anlamda bir artışa sebep olmuştur. "Diğer bir deyişle, belli bir toplumsal katmanın ilişkilerini, belirli bir temaya ve belirli niteliklere sahip bir oyuncu kadrosuyla sürdüren tekil bir televizyon dramasının sağladığı 'başarı' çok sayıda benzerinin yapılmasını kışkırtan bir etki yaratmıştır (Çelenk, 2005, 291)”.

Böylece televizyonda, 90’lı yıllar boyunca ağırlıklı olarak yabancı kaynaklı dramalara ve formatları yine yurtdışından alınmış yerli drama veya komedi dizilerine yer verilmiştir. Bu yıllar boyunca konular genellikle; doktorların, hastaların, sağlık personelinin, gazetecilerin, polislerin, suçluların, mafya mensuplarının, avukat ve kurbanların öykülerinin etrafında şekillenmiştir (Çaplı, 2002, 124). Ancak 2000’li yıllara gelindiğinde ticari televizyon yayıncılığında öncekine benzemeyen bir değişim yaşanmış ve Anadolu'yu mekan olarak seçen, geleneksel toplumsal ilişkileri konu alan yerli dramatik yapımlar (Deli Yürek, Zerda, Berivan, Kınalı Kar, Asmalı Konak vb.) belirgin bir eğilim haline gelmiştir. Böylece kamera belki de bu kadar yoğun biçimde ilk kez taşraya dönmüş; ağa, bey gibi feodal yapının izleyiciye cazip gelen unsurlarına yer vermiştir (Çelenk, 2005, 304-305). Bu dönüşüm, yerli yapımların hâkimiyeti, Türk televizyonlarına has önemli bir özellik olmuştur.

Takip eden yıllarda yerli diziler bir dönüşüm daha geçirmiştir. 2000’li yılların ortalarına doğru tekrar İstanbul'a dönen hikaye örgüsü bu sefer de İstanbul'un burjuva kesimine odaklanmış; lüks evler, lüks semtler ve lüks arabaların içinde yaşayan kahramanlarına kentin genel tabakasına hiç de benzemeyen bir profil çizmiştir. Bu değişimin ikinci aşaması da, güncel detaylarla donatılan, klasik edebiyat eserlerinin tekrardan televizyon dizisi olarak uyarlanması olmuştur. Aşkı-Memnu, Dudaktan Kalbe ve Yaprak Dökümü gibi Klasik Türk Edebiyat'ının önemli eserleri, hikayenin geçtiği zamanın değiştirilmesi yoluyla tekrardan gündeme gelmişlerdir. Bu yeniden uyarlamalar, televizyon drama yapımlarında en çok kullanılan unsurlardan bazıları olan; aşk ve romans, fantezi, intikam, tehlike-yaşamı sürdürme, grup ve aile bağları, geri dönüş, başarı gibi unsurları da sıkça kullanmaktadırlar (Kars, 2003, 148). Böylece dramatik yapıyı güçlü tutarak izleyiciyi yüksek izlenme oranlarıyla kendilerine bağlamaktadırlar.

Dram sözcüğü Eski Yunancadaki anlamı ile hareketi temsil etmektedir. Ancak bu hareket; öznesi, amacı ve etkisi olan bir eylemdir yani başlar, gelişir ve bir sonuca ulaşır (Şener, 1997, 15). Drama, görselliğe ulaştırılmış bir anlatım, zamana göre hareketlendirilmiş bir resimdir. Böylece olay örgüsü zaman içinde, sözcüklerin birbiri ardına geldiği çizgisel bir biçim ile gelişim göstermektedir (Esslin, 1996, 31). Televizyon draması da aynı şekilde "bir öyküye ve öykünün geliştirdiği olay örgüsüne dayandırılmak durumundadır. Olay örgüsünde, olaylar arasında nedensellik ilișkisinin kurulması gereklidir. Olay örgüsünü oluşturan küçük olaycıklar birbirine neden-sonuç ilişkisiyle bağlanırlar (Kars, 2003, 144)”. Bu olaycıklar kimi zaman sert ve duygu yüklü yüksek çıkışlarla yaşanırken kimi zaman ise içinde az veya çok 
komedi unsurunu barındıran ve ailenin gündelik yaşamına giren anlardan meydana gelmektedir. Burada önemli olan unsur olaylar arasındaki nedensellik bağının hem izleyiciyi yormayacak basitlikte kurulması hem de dikkatini başka yöne yöneltmesine firsat vermeyecek yoğunlukta olmasıdır.

Özellikle prime-time kuşağında hemen hemen 2-4 saat arası yayınlanan dizilerin, yüksek reyting alan bütün ulusal kanallarda yayınlandığı düşünülürse etkisi az çok tahmin edilebilir. Özellikle günümüzde ekonomik zorlukların eve kapattığı televizyon izleyicisi, sosyal doyumu neredeyse bir tek yerli yapım drama dizileri ile sağlamaktadır. Bu yönüyle olay örgüsü yoğun, bol acıyı, gözyaşını ve zaman zaman şiddeti barındıran bu yapımlar, izleyiciyi ekran karşısına sabitleyerek onu hayatın gerçekliklerinden uzaklaştırabilmektedir.

Kadın kimliğini ele alış biçimi bakımından Yaprak Dökümü dizisi, çekildiği yıllar içinde ve aynı zamanda geçen zaman rağmen güncel yapımlar içinde de önemli bir yere sahiptir. Birden fazla ve farklı kadın kimliğinin aynı yapım içerisinde işlendiği Yaprak Dökümü dizisi bu değerlendirmeyi detaylı bir araştırmaya dönüştürmek bakımından verimli bir örnektir. Böylece dizi içerisinde farklı sınıflara, statülere, eğitimlere ve değer yapılarına sahip birçok kadının aynı yapım içerisinde karşılaştırmalı olarak değerlendirilmesi olanaklı hale gelecektir. Bu nedenle Yaprak Dökümü dizisi hem izlenme oranları hem de kadın kimliğini temsil edişi bakımından önemini halen koruyan diziler arasında bulunmaktadır Tekrar gösterimlerinin olması, dizinin halen izleyici kitlesi ile buluşuyor olmasının da önemli göstergelerinden biridir.

\subsection{2. "Yaprak Dökümü” Dizisinde Kadın Kimliğinin Temsili}

- Eser: Reşat Nuri Güntekin

- Senaryo: Ece Yörenç, Melek Gençoğlu

- Yönetmen: Mesude Eraslan

- Yapımci: Kerem Çatay

- Yapım: Ay Yapım

- Yayına Başladığı Tarih: 2005

- Son Bölümün Yayınlandığı Tarih: 2010

- Yayınlandığı Kanal: Kanal D

İlk baskısı 1930 yılında yapılan roman, Reşat Nuri Güntekin tarafından kaleme alınmıştır. Romanda, batılı olmaya öykünen toplumun değerlerini kaybediși anlatılmıştır. İlkelerine oldukça bağlı olan Ali Rıza Bey'in toplumsal çözülme içinde ailesini ve değerlerini kaybediși konu edilmiştir. Eser ilk olarak 1988 yılında TRT için televizyona uyarlanmış ve yayınlandığı dönemde oldukça ilgi görmüştür. İlk uyarlama dönem özelliklerini taşımakla birlikte 2006 yılında ikinci kez uyarlanan ve çalışmanın konusunu oluşturan Yaprak Dökümü, güncel bir dille, gündelik hayatın detaylarını içine alarak senaryolaştırılmıştır. Dizi hem bu yönden hem de eserin orijinal yapısının bozulduğu yolundaki yorumlarla sık sık eleştirilmiştir. İkinci kez uyarlanan dizide genel konu sabit kalmakla birlikte sürenin uzatılması ve dramatik yapının desteklenmesi gibi nedenlerle dizinin içine küçük öykü ve hikâye eklemeleri yapılmıştır.

Ana hatlarıyla öykü; kaymakamlıktan emekli olan Ali Rıza Bey'in ailesi ile birlikte İstanbul'a gelişinin ardından yaşadığı çözülmeden bahsetmektedir. Öncelikle oğlunun, evlenmiş ve boşanmış bir kadın olan Ferhunde ile evliliği, bu evliliğin getirdiği felaketler, sonrasında birbirine yakın yaștaki iki kız kardeșin aynı adama 
ilgi duyması ile yaşananlar ve bütün bunlara eklenen maddi zorluklar hikayenin ana hatlarını oluşturmaktadır. Temelde farklı kadın imgeleri üzerinden ilerleyen dizide; mağdur, masum, ilkeli, uyanık, fettan, iyi ve kötü kadın imajlarının hepsi birden bulunmaktadır. Bu nedenle seyircinin ilgisini uyanık tutacak, sevilen-nefret edilen, çatışma yaratacak karakter ikilemi doğru işlenmiştir.

Diğer taraftan süreç boşluk kalmayacak şekilde doldurulmuş, izleyiciye düşünme ve konudan uzaklaşma fırsatı vermeyecek şekilde dramatik yapıya ağırlık verilmiştir. Bu ve benzeri standartları sağlamıș olması diziyi beğenilen diziler arasına sokmuștur. Ancak burada konu edilen dizinin bu yönde elde ettiği başarı değil kadın kimliğine yer veriş biçimidir. Bu nedenle öncelikle dizide yer alan kadın karakterler incelenecek ve yer alış biçimlerinin eleştirisi yapılacaktır.

Dizinin baş kadın kahramanlarından, ailenin annesi Hayriye Hanım, ev hanımı kimliği ön planda olan ve hayatı boyunca herhangi bir görevde bulunmamış, çalışmamış geleneksel bir Türk annesi imajına sahiptir. Hayriye Hanım, eşinin ilkelerine onun kadar inanmayan, hayatın gerçeklerini eşinden daha doğru gördüğünü düşünen bu nedenle de zaman zaman çıkarlarını ön planda tutarak bazı kurnazlıklar yapan bir kadındır. Ali Rıza Bey kaymakamlıktan emekli, eğitimli ve edebiyata olan ilgisiyle de kültürel birikimine yatırım yapan biridir. Bu nedenle birçok konuda karısıyla ayrışır ve anlaşmazlıklar yaşar, zaman zaman da eşini alttan alta hor görür. Bütün bu yönleriyle Hayriye Hanım, geleneksel anne-eş kimliklerini temsil etmektedir. İyi eğitim almış bir kişi ile evlenmiş bu yolla da statü kazanmıştır. Bundan sonra onun için evine yuvasına bakmak ve çocuklarını büyütmek önemli olmuştur. Hayatla ilgili endişeleri ve kaygıları da sadece çocuklarının hikayeleri üzerinden yaşanmış, onların mutluluğuyla mutlu olmuş, mutsuzluğuyla kederlenmiştir. Kısacası Hayriye Hanım dizi içinde yarattığı kimlikle "saçını süpürge etmiş" hayatını çocuklarına ve ailesine adamış bir anne rolünü simgelemektedir. Geleneksel bir kimlik olmasıyla genel kabul gören Hayriye Hanım karakteri, evi geçindirmek ve para kazanmak zorunda kalmamış olmasıyla kocasının gerisinde durmaktadır. Aile içinde kararlar evin "reisi" olan baba tarafından verilmektedir. Geleneksel Türk aile yapısı çoğunlukla bu göndermeyi doğrulamakta ve geleneksel ifadeler bu yolla sağlamlaştırılmaktadır. Ailenin annesi olan kadının karar vermesi ancak çevirdiği entrikalar ve gerçeklerin gizlenmesi yoluyla mümkün olabilmekte, kadın özellikle erkek dünyasına ait görünen konularda eşin kararını kabul etmek durumunda kalmaktadır. Kabul etmediği noktada da tartışmalar yaşanmaktadır. Yaratılan diğer bir imaj ise anne olan, ev kadını olan kadın karakterin aslında dış dünyaya ait konularda yetkin olmadığı, kararı verecek kadar bilgili olmadığı șeklindedir.

$\mathrm{Bu}$ nedenle hikayenin alt metni okunduğunda kadınının, dış dünya konusunda yeterli bilgiye sahip olmadığı, hayatını yönetebilmek için erkek becerisine ve iradesine ihtiyaç duyduğu konusunda bir vurgulama yapılmış olduğu görülür. Genel bir ifadeyle Hayriye Hanım karakteri geleneksel Türk kadının bütün kodlarını içinde barındıran bir yapıya sahiptir.

Karşı cephede bulunan ve genellikle nefret duyulan kadın ana karakterlerin başında ise Ferhunde gelmektedir. Ferhunde evin büyük oğlu Şevket'le evlenmiş böylece aileye gelin olarak gelmiştir. Evin büyük oğlu Şevket iyi huylu, saf bu nedenle de sık ve kolay etki altında kalabilen biridir. Dizinin fettan, uyanık ve kötü kadını Ferhunde ile evlenmesi de, Ferhunde'nin bu saflığı kullanmasıyla olmuştur. O sırada evli 
olan Ferhunde bir akşam Şevket'i evine çağırmış, kocasının eve gelmesi üzerine de içine düştüğü kötü durumdan kurtulmanın yolunu Şevket'e evlenmek olarak göstermiștir. Ailenin bütün itirazlarına karşın Şevket ile Ferhunde evlenmiş ancak Ferhunde'nin fettan ve kurnaz bir kadın olması, çeşitli oyunlar çevirmesi nedeniyle mutlu olamamışlardır. Aile bu evliliğe öncelikle Ferhunde'nin "dul” bir kadın olması nedeniyle karşı çıkmıştır. Genellikle bekârete vurgu yapan "dul” ifadesi yine Türk kültürü içinde genel bir onaya sahiptir. Erkeğin karşı cins ile ilgili tecrübesi onay görmesine karşın kadının evlilik öncesinde herhangi bir ilişki - özellikle cinselliğin yașandığı bir ilișki - yaşaması ret görmektedir. Kadının saf, masum ve özellikle bakire olması idealize edilen bir tutumdur. Bu gibi nedenlerle kadın, evlenip boşanması halinde ancak ya kendi gibi "dul" bir erkekle evlenmeli ya da hayatı boyunca ilişki yaşamamalıdır. Ferhunde toplumsal onaya göre yapılmayacak olanı yapıp daha önce evlenmiş bir kadın olarak hiç evlenmemiş bir erkeği "ayartmıștır". Ancak zaten Ferhunde dizinin kötü geçmişi nedeniyle biraz şüpheli, fettan kadınıdır. Bu yönüyle nefret edilen karakter olmasına karşın zaman zaman öne çıkarılan mağduriyeti ile de özdeşleşmeye olanak sağlayabilmektedir. Babası küçük yaşta ölmüş olan Ferhunde bir süre üvey babası ve annesi ile yașamıș ancak kendisini taciz etmesi üzerine annesi üvey babayı öldürmüș ve hapse girmiștir. Trajedi bundan sonra da Ferhunde için devam etmiş, geçimini sağladığı bir mesleği olmasına karşın hayatını devam ettirebilmek için evlenmeye ve bir erkeğin koruması altına girmeye mecbur kalmıștır.

Bu noktada getirilebilecek en önemli eleştiri Ferhunde'nin geçimini sağlayabildiği halde sürekli bir evliliğe ve bir erkeğin korumasına duyduğu ihtiyaçtır. Bazı bölümlerde belli belirsiz bir şekilde bu durum eleştirilse de özellikle izleyici de yaratılması hedeflenen özdeşleşme söz konusu olduğunda, bu mağduriyet kullanılmakta, izleyici Ferhunde'yi ancak aciz ve korunmaya muhtaç gördüğü durumlarda benimsemektedir. Bunun yanı sıra güzel ama fettan ve genellikle cinselliğini ön planda tutarak ayartıcı olan kadın imgesi, Ferhunde'nin karakterinde tekrardan kötü kadın imgesiyle pekiștirilmektedir. Böylece cinselliğini ön plana çıkararak erkekleri ayarttı̆̆ı, çeşitli kurnazlıklar ile kötü kadın imgesini yarattığı sahnelerde nefret edilen; mağdur ve korunmaya muhtaç olduğu sahnelerde de benimsenen ve onaylanan Ferhunde karakteri dizinin en ilgi çeken karakterlerinden biri durumundadır.

Dizinin en mağdur kadın karakterlerinden biri evin büyük kızı Fikret'tir. Fikret babasının görevi nedeniyle bulunduğu bir kasabada nişanlanmış ancak nişanlısının babasının adı haksız kazanç sağlanan bazı işlere karışınca hiç düşünmeden sevdiği adamdan ayrılmıştır. Fikret tam anlamıyla babasının kızıdır. Onun kadar, mağrur, onuruna düşkün, onun kadar kuralcı ve mantıklıdır. Ancak bu özellikler bir kadından çok genellikle bir erkeğe atfedildiğinden, Fikret’te de bazı kadınsı özellikler görülmez. Öncelikle ismi erkek ismidir ve muhtemelen istekle beklenen bir erkek çocuğu, kız olarak doğduğunda yaşanan hayal kırıklığına rağmen değiştirilmemiştir. Babasına hayran olarak büyüyen Fikret, onun taleplerinin dıșına hiç çıkmamıștır. Neredeyse gençlik asiliği bile yaşamamış, kendi ergenliğinde dünyaya gelen kız kardeşine erken bir annelik bile yapmıştır. Her șeyden önce bir ev kızı olarak yetiștirilmiștir, dantel örer, evin temizliğine yardım eder. Okumamış olmasına rağmen yine aynı babası gibi edebiyata düşkündür. Bu nedenle de diğer kardeşlerinden farklı olarak daha rasyoneldir ve daha akılcı kararlar alabilmektedir. Fikret hemen hiçbir zaman diğer kadınlar gibi duygularına yenik düşmez. Fikret asla kadınsılığını ön plana 
çlkarmaz, sanki onun cinselliği yoktur. Sevdiği, evlenmek üzere olduğu adamdan bu gibi nedenlerle kolayca vazgeçebilir. Fikret, İstanbul'a geldiklerinde de yaşamındaki hiçbir şeyi değiştirmez. Diğer kardeşlerinin aksine o, bu yeni dünyanın büyüsüne kapılmaz. Kardeşlerinin bu yeni hayat karşısında, "yozlaşmaları" onu hayrete düşürür. Fikret'in hayatındaki kırılma ise tam bu noktada meydana gelir.

Yaşananlara tahammül edemediği bir an evden uzaklaşmak adına hiç tanımadığı bir adamla evlenmeyi kabul eder. İstediği tekş̧ey ailenin çürümeye yüz tutmuş, çözülmeye başlamış olan bu yeni hayat tarzından uzaklaşmaktır. Böylece hiçbir zaman babasının çizdiği çizgi dışına çıkmamış olan Fikret ailesinden kopar. Fikret'in tek çıkış noktası evliliktir. Fikret ev kızı olarak büyütülmüștür. Kardeşleri gibi okumamış herhangi bir işte çalışmamıştır. Onu aile evinden çıkartacak tek şey yapacağı evliliktir. Fikret'in içinde bulunduğu çıkmaz aslında kadının gerçek hayatta defalarca yüzleştiği bir çıkmazdır. Okuma fırsatı bulamamıș, kendine hayatını kazanacağı bir iş edinememiş olan kadının hayattan beklediği tek firsat baba evinden koca evine gitmek olacaktır. Böylece kadının vesayetinin babadan alınıp kocaya verilmesi ile arada boşluk kalmayacak şekilde kadın üzerindeki kontrol sağlanmış olacaktır. Kadın zamanı geldiğinde - ki bu çok da gecikmemelidir - evini, yuvasını kuracak sonrasında mutlu da olsa mutsuz da olsa sesini çıkarmadan düzeni devam ettirecektir. Geleneksel yapının düzenin devam etmesini garanti altına alacak olan ve çözülmemesi gereken yapılardan biri de bu aile yapısıdır. Kadın kurulmuş olan o düzenin içinde tahammül eden, idare etmesi gereken "dişi kuş" olarak görev almalıdır. Fikret'in hayatı da benzer bir çizgide ilerler. Evlendiği adamın ölmüş olan eski karısından üç çocuğu vardır. Fikret önce onlara annelik yapar. Sonra evlendiği bu yabancı adama alışmaya çalışır. Sevmese bile ona alışmalıdır. Bütün bu olumsuzlukların, kendi ailesinde yaşanan çalkantıların üstüne bir de "kaynana" sorunu yaşar. Fikret'in kayınvalidesi Cevriye Hanım, oğlu kiminle evlenirse evlensin kabul etmeyeceği gibi Fikret'i de istemez. Yine geleneksel yapı içinde sıkça karşılaşılan kayınvalide-gelin çatışması oldukça şiddetli biçimde yaşanır. Ancak Fikret dirayetli, güçlü bir kadın olarak bütün bu zorlukların üstesinden gelir ve çok zaman pes etme noktasına gelse de yuvasını bozmaz. Kadına biçilmiş olan görev Fikret'in yaptıkları ve yapmadıklarında net olarak ifade edilmektedir. Kadın yaşadığı her türlü zorluğa göğüs germeli ve evini bırakıp gitmemelidir. Toplumsal onayı ancak bu yolla alır. Kadının güçlü ve toparlayıcı olduğu üzerine yapılan bu vurgu ile aile kurumunun olası çözülme ihtimali engellenmeye çalışılır.

Dizi içerisindeki kadın karakter yapılarındaki farklılaşma ortanca iki kız kardește de devam eder. Leyla komşularının kızı Sedef vasıtasıyla Oğuz'la tanışır. Oğuz dizi içindeki kötü erkek karakterlerden biridir ve iki kız kardeşle birden flört eder.

Ancak Leyla'nın Oğuz'un evine gittiği bir gece, Oğuz zorla Leyla ile birlikte olur. Bekâretini kaybetmiş olan Leyla bundan üzüntü duysa da Oğuz'la beraber olmaya devam eder. Hamile olduğunu öğrendiği gün Oğuz'un evine gittiğinde onu iş ortağının karısıyla yakalar ve yaşadığı panikle merdivenlerden düşerek bebeğini kaybeder, hastanelik olur. Ailesinin de hastaneye gelmesiüzerine Leyla'nın hamile kalmışolduğu öğrenilir. Ali Rıza Bey aldığı ani kararla Leyla'yı Oğuz'la evlenmek zorunda bırakır. Eğitimli, okumuş bir adam olan Ali Rıza Bey dahi sadece "namus"unu kurtarmak adına hiç de onaylamadığı bir adamla, kızını evlilik yoluna itebilmektedir. Burada önemli olan kızının mutlu bir hayat sürmesi değil kaybedilenin yerine konmasıdır. Bu bölümlerde kaybedilen "namus" kavramı üzerinde durulur. Özellikle Fikret'in bu 
evliliğe itirazının altında bir birlikteliğin bu gibi bir sebeple kurulmaması gerektiği yatmaktadır. Ancak bütün itirazlara rağmen Leyla kendini aldatan bu adamla evlenir. İlk günlerdeki mutsuzluğu zaman içinde kocasının ona sağladığı lüks yaşam ile yer değiştirir. Leyla orta sınıf, memur bir ailenin kızıyken şimdi zengin bir erkeğin karısı olarak sınıf atlamıştır. Ancak Leyla'nın hiçbir çaba göstermeden elde ettiği bu konum kısa ömürlü olur. Oğuz kardeşi Necla ile birlikte kaçarak Leyla'yı bırakır. Leyla bu terk edilmenin ardından ciddi psikolojik sorunlar yaşar, uzun süre kendine gelemez ve dizinin mağdur kadın karakterlerinden biri haline dönüşür. Yaşadığı bu erken evlilikle okul hayatı da yarıda kalan Leyla kısa bir dönem çalışsa da ileride yine çözümü bir erkeğe sığınmakta bulacaktır.

Diğer ortanca kız kardeş Necla, Leyla'ya kıyasla daha güçlü bir duruş sergiler. Leyla duygularına kapılıp giderken, Necla daha dik durabilmeyi başarmaktadır. Necla bir hata yaparak kardeşinin kocası olan Oğuz'la kaçsa da yanlışından kısa sürede dönerek ailesinden uzakta hayat mücadelesi vermeye başlar. Bu kaçış ile birlikte aile tarafından reddedilen Necla bir yandan çalışmakta bir yandan da okumaktadır. Ailesi tarafından da affedilen Necla, Leyla'ya göre daha şanslıdır. İyi ve zengin bir ailenin oğlu olan Cem'le bir evlilik yapar. Cem'in ailesi tarafından onay görmese de kavuştuğu bu yeni ve zengin yaşamın tadını çıkarır. Lüks ve büyük bir sitede oldukça lüks ve büyük bir evde oturur. Kocasıyla birlikte yurtdışı tatillerine gider, pahalı elbiseler giyer. Ancak yeniden tekrarlanan vurgu kadının "iyi" bir evlilik yaparak, lüks ve zengin bir hayata kavuşabileceği şeklindedir.

Bunlar kazanılmış olan haklardan daha çok edinilmiş olan haklar olarak yer bulur. Özellikle orta ve alt sınıftan izleyici, idealize edilen bu yaşam şekliyle, ulaşması gereken hedefi görür. Denilmektedir ki bu lüks ve zengin yaşam, evlilik yoluyla elde edilebilen ve hedeflenebilecek olan bir konumdadır. Kadının kazanımları genellikle ya aileden gelmekte ya da evlilik yoluyla elde edilmektedir. Dizilerin genelinde kadın bu kazanımı kendi başına elde edemez.

Görülmektedir ki kadının Yaprak Dökümü dizisi içindeki konumlandırılışı geleneksel yapıdan ayrı bir görünüm sergilememektedir. Geleneksel yapı içinde bulundurulan bütün dinamikler ve kodlar aynı şekilde dizinin ana kadın karakterlerinde yer almışlardır. Bu yönüyle standardın dıșına çıkan bir karakter yapısına rastlanmamıştır. Hayriye Hanım geleneksel anne ve eş konumundayken, Ferhunde kötü kadın imajını yansıtmaktadır. Terbiyeli, kuralcı ve güçlü kadını simgeleyen Fikret ile toplumsal çözülmeyi anlatan Leyla ile Necla hemen bütün karakter özellikleriyle yerli yerinde durmaktadırlar.

Son olarak eserin bir uyarlama olduğu ve neredeyse 80 yıllık bir süre önce yazıldığı, bu nedenle de çağın dinamiklerini yansıtmak zorunda olmadığı eleştirisi yapılabilir. Öncelikle sosyal bir olgu olarak kadın kimliğinin, 2005 yılında çekilmeye başlanan Yaprak Dökümü dizisi üzerinden anlaşılmaya çalıșıldığı söylenmelidir. Burada hedef, eserin kendisi değildir, çok izlenen bir dizi olan yapımın halen kabul görmesi esas alınarak buradan kadın kimliğinin yer alış biçimine ulaşılmaya çalışılmıştır.

Dizinin yayınlandığı tarihlerde yüksek izlenme oranlarına sahip olması bu yönüyle benimsendiğini göstermektedir. Yayınlandığı tarih üzerinden geçen zamana rağmen değişimin kadın kimliğinin özgürleșmesi yerine bazı teknolojik detaylarda meydana gelmesi dikkat çekici bir unsurdur. 1930’lı yılların Türkiye'sinde yazılan bir roman, 2005'in Türkiye'sinde halen rahatlıkla kabul görmektedir. Bu da göstermektedir ki 
yaşanan değişim kadının özgürleşmesi gibi kritik noktalardan çok detay sayılabilecek bazı kısımlarda meydana gelmiştir.

\section{Sonuç}

Kadının toplumsal alandaki konumu hem dünyada hem de Türkiye'de dikkat gösterilmesi gereken bir noktadadır. Kadın yaratılmış olan toplumsal farklılıklar nedeniyle erkekle eşit statüye sahip olamamakta bu ikincil konumuna karşın ağır sorumluluklar almaktadır. Kadın, toplumsal yapı içerisinde töre cinayetlerinden, uygulanan fiziki veya psikolojik şiddete, sosyal ortam ve çalışma hayatı içinde yeterli derecede yer alamamasından eğitimsizliğe birçok sorunun merkezinde bulunmakta ve bu konuda gerçekleştirilen çalışmaların kadının toplumsal yapı içerisindeki konumunu iyileştirecek bir çabaya sahip olması gerekmektedir.

Kadının işini kolaylaştıracak toplumsal düzenlemelerin yapılması ve kadının özellikle ev-içi sorumluluğunun azaltılması gerekmektedir. Ancak böyle bir gelişim, öncelikli olarak hem erkeğe hem de kadına gerekli olan doğru eğitimin verilmesinden geçmektedir. Anne-baba olarak kız ve erkek çocuğun yetiştirilmesinde sorumluluk sahibi olan bireyler bu konuda eşitlikçi ve doğru bir tavır sergilemeli özellikle toplumsal alandaki sorumlulukların paylaşımında cinsler arası ayrım gözetilmemelidir. Diğer taraftan kadına meslek kazandırma konusu önemsenmeli, kadının işgücü olarak ikincil konumu ortadan kaldırılmalıdır. Ancak bu yapılırken kadının yükü daha da ağırlaştırılmamalı, ev-içi sorumluluklar cinsler arasında eșit olarak paylaşılmalıdır. Alınan bu gibi önlemlerle, az da olsa kadının toplumsal alan içindeki konumunda değişimler meydana getirilebilir.

$\mathrm{Bu}$ perspektiften bakıldığında, kadın ve medya ilişkisi yeterli analiz yapıldığında kadının toplum içindeki konumlandırılışına dair önemli ipuçları taşımaktadır. Birbirine bağlı olan bu halkalar, değișim yaratma konusunda da birbirlerinden etkilenmektedirler. $\mathrm{Bu}$ nedenle özellikle kadının medyadaki konumlandırılışına dair yapılan çalışmalar sorunun hangi aşamada olduğunu ve nasıl çözüme kavușturulacağını ortaya çıkarmakta faydalı olabilir. Denilebilir ki medya büyük oranda toplumsal dinamiklerle karşılıklı bir etkileşim içindedir. Bu nedenle kadının toplumsal temsili konusunda da önemli bir belirleyici konumundadır.

Medyanın bir toplumsallaştırma aktörü olarak görev yaptığı düşünülürse kadın kimliğinin ifade edilmesi konusunda ilkeli olması beklenebilir. Kadını; hayatını yönetmekte söz sahibi olmayan, karar verme sürecine katılamayan, şiddet gören, okuyamayan, çalışamayan ikincil bir konumda gösterdikçe ancak var olan düzen pekiştirilmektedir. Birincil görevi halkı eğitmek olmasa dahi bu konuda yönlendirici olduğunu göz önünde bulundurarak gerekli dikkati gösterir ise kendi adıma olumlu bir adım atmış olacaktır. Belirlenmiş stereotipleri pekiştirmek yerine kadına, toplumsal eșitliği yansıtan ya da en azından bu eleştiriyi getirebilecek yapımların ekranlarda olması, medyadaki değişimin önemli adımlarından biri olarakgörülebilir. Burada medyanın alabileceği ya da alması gereken en önemli tedbir, özellikle çok izlenen yerli dramalar gibi yapımlarda, geleneksel rollerin sert çizilmiş sınırlarını yumuşatarak, cinsiyetçi olan bir dilden uzaklaşması olabilir. Özellikle kadınlar için belirlenmiş olan kalıpların yeniden gözden geçirilmesi bile bu konuda medyada önemli bir değiş̧im yaratacaktır. Bu yönden değerlendirildiğinde ekranlarda olduğu yıllar boyunca "Yaprak Dökümü" dizisi hemen tüm medya alanlarında olduğu gibi stereotipleri kullanmayı tercih etmiştir. Buradaki en belirleyici unsur hiç kuşkusuz 
ki izleyici ekran başına çekebilmektir. Bu noktada en önemli sorulardan biri sorulabilir. Medya mı izleyiciyi şekillendirmektedir? Yoksa izleyicinin taleplerini mi yerine getirmektedir?

\section{Kaynakça}

Arat, N. (1996). “Türkiye'de Kadınların Çalıșma Yaşamında Karşılaştıkları Zorlukların Sosyo-Kültürel Nedenleri”, Der: Necla Arat. Türkiye'de Kadın Olmak, 2. Basım. İstanbul: Say Yayınları.

Butler, J. (2008). Cinsiyet Belasi: Feminizm ve Kimliğin Altüst Edilmesi, İstanbul: Metis Yayınları.

Cankaya, Ö. (2003). TRT Bir Kitle İletişim Kurumunun Tarihi 1972-2000. İstanbul: Yapı Kredi Yayınları.

Connell, R. W. (1998). Toplumsal Cinsiyet ve İktidar. İstanbul: Ayrıntı Yayınları.

Çaplı, B. (2002). Medya ve Etik. Ankara: İmge Yayınları.

Çelenk, S. (2005). Televizyon Temsil Kültür. Ankara: Ütopya Yayınevi.

Elmacı, N. (1996). "Poligami: Çok-Eşli Evlilikler”, Der: Necla Arat. Türkiye'de Kadın Olmak. 2. Basım. İstanbul: Say Yayınları.

Esslin, M. (1996). Dram Sanatının Alanı. İstanbul: Yapı Kredi Yayınları.

Güvenç, B. (1999). İnsan ve Kültür. 8. Basım. İstanbul: Remzi Kitabevi.

Hablemitoğlu, Ş. (2004). Toplumsal Cinsiyet Yazıları. İstanbul: Toplumsal Dönüşüm Yayınları.

Kandiyoti, D. (1997). Cariyeler, Bacılar Yurttaşlar. İstanbul: Metis Yayınları.

Kars, N. (2003). Televizyon Programı Yapalım Herkes İzlesin. İstanbul: Derin Yayınlarl.

Kottak, P. C. (2001). Antropoloji. Ankara: Ütopya Yayınevi.

Nare, S. (1996). “Kahramanlık ve Toplumsal Cinsiyet”, Der: Necla Arat. Kadın Gerçeklikleri. İstanbul: Say Yayınları.

Oskay, Ü. (2000). Kitle İletişiminin Kültürel İşlevleri. İstanbul: Der Yayınları.

Şener, S. (1997). Yaşamın Kırılma Noktasında Dram Sanatı. İstanbul: Yapı Kredi Yayıncilık.

Türkoğlu, N. (2000). Görü-Yorum Gündelik Yaşamda İmgelerin Gücü. İstanbul: Der Yayınları.

Zoonen, V. L. (1996). "Medyada Feminist Yaklaşımlar”, Der: Süleyman Irvan. Medya Kültür Siyaset. Ankara: Ark Yayınları. 
